\title{
Problems in Teaching Tenses to Turkish Learners
}

\author{
İsmail Çakır \\ Department of Foreign Languages, Faculty of Education, Erciyes University, Kayseri, Turkey \\ Email: ismailcakir@erciyes.edu.tr
}

\begin{abstract}
This study focuses on the problems in teaching tenses to Turkish students at university level in Turkey. Some of the problematic and confusing tenses such as Past Simple and Present Perfect Tense, Present Continuous and Present Simple, Past Simple and Past Continuous Tense Teaching grammar have been handled throughout this study with the data obtained from the written exams of the learners. Most frequently occurred errors have been listed and they have been analyzed in detail. The findings reveal that the reasons for these errors mostly derive from mother tongue interference and lack of adequate linguistic background. The other component of this article is to offer remedial teaching activities for foreign language learners to compensate the shortcomings.
\end{abstract}

Index Terms — tenses, grammar, mistake, error, foreign language, mother tongue interference, teaching

\section{INTRODUCTION}

In foreign language teaching process, teaching grammar is one of the stressed points that teachers cannot disregard. Despite the various views whether it should be presented or not, there is a general agreement that a systematic and purposeful teaching of it vital to master the target language. Grammar, either directly or indirectly, is taught from the elementary education until the undergraduate studies for about eight years in Turkey. Thus, every student has to learn grammar for about eight years long. However, it is observed that in spite of teaching grammar so extensively, students are unable to produce grammatically correct sentences. Students suffer from English phobia and join courses to develop their linguistic competence even after completing their graduation.

Generally speaking, the teaching of grammar has been regarded as a highly structure based and formal activity in many of the schools in Turkey. In most cases, grammar is exclusively taught for its own sake. The general pattern for the teaching of grammar is to give some rules using a lot of technical terminology, talk about the exceptions to the rules, ask students to solve some exercises that are often mechanical and monotonous and this is the end of the teaching of grammar. Even if the students' performance in a grammar test is fairly good, there is no guarantee of the fact that he would be able to speak and write in English well. In this respect, Gokhale (2010) claims that in most cases, grammar is taught as an end in itself rather than as a means to an end. Ideally, the teaching of grammar must help our students to produce utterances that exemplify the grammatical rules, but it seems that generally the teacher focuses on teaching the rules of grammar and ignores the communicative aspect of language.

Put other way, grammar which is composed of tenses is an indispensable part of a language and it constitutes the bone of the body, language. Hence, they need to be learned or acquired by the learner either consciously or subconsciously. As it has a certain role in language teaching, the teachers of foreign language need to tackle with it within the teaching syllabus skilfully so that the learners can grasp it well.

Before talking about tenses in English it would be better to drop a few lines of grammar, in which tenses have a certain role. Grammar exists in languages and will be learned or acquired in a way. For the native speakers, according to Chomsky (1959), grammar is somewhere in their brains and they can use to make sentences. The hypothesis that the course of language acquisition is determined by an innate faculty is known popularly. Chomsky maintains that language activity is an activity unique to human beings experience, so that learning a language involves mental processes. When it comes to foreign language learners the situation seems to be a bit different considering that they already know a language, mother tongue, and they will build a new one on it. So if a learner would like to approximate the competence of a native speaker, he should have some capacities such as the ability to distinguish grammatical from ungrammatical sentences. He should also be able to produce and understand an infinite number or grammatical sentences, and identify syntactically ambiguous sentences. Learning a language does not consist of only approximation to the native speaker, and the learner may have slips, mistakes, false starts and a number ungrammatical behaviours.

Needless to say, Turkish students have some difficulties in learning some tenses due to some reasons originated from their misunderstandings or misinterpretations of the lessons presented by the Turkish teachers. Mother tongue interference can also be regarded as an important barrier that keeps the learners learning the newly confronted language. We always encounter with the misused sentences produced by the students such as, "I have seen that film last year", "*I am living in Ankara", "*I told him he is at home", "*I am playing football on Sundays", "I was go to Istanbul last summer", "I was knowing that you couldn't come", "I am understanding now" and so forth. As a teacher of foreign language, what should be done is to make some remedial teaching on the misunderstood and fossilised concepts located in the students' minds. Hence, this study aims at presenting these misconceptions and problems arising in teaching 
some tenses. Before moving to the problems in teaching tenses to present some general information about grammar will help to clarify our issue in concern.

\section{TEACHING GRAMMAR}

It is a fact that while teaching tenses we teach grammar of the language in question. Ur (1996) defines grammar as "the way words are put together to make correct sentences (p.75)". Radford (1998) characterises grammar as the study of the principles which govern the formation and interpretation of words, phrases and sentences. To Crystal (1992) Grammar is a systematic analysis of a language (p.158). It has also been known that grammar is traditionally divided into morphology and syntax.

We can say that grammar is abstract in the mind and it becomes concrete in the use. That is to say, it is something that is somewhere in the brain and turns out to be concrete in using. Moreover, it is the study of grammatical competence which means tacitly knowing about the grammar of a language. To introduce a technical term, we might say that native speakers have grammatical competence in their native language; by this we mean that they have tacit knowledge of their language. In other words, they are aware of how to form and interpret words, phrases and sentences in the language. So human beings have no conscious awareness of the psychological processes involved in speaking and understanding a language.

In a word, a grammar of a language is a model of the competence of fluent speaker of the language, and competence is reflected in intuitions about grammaticality and interpretation. A grammar of a given language is descriptive adequate if it correctly describes whether any given string of words in a language is or isn't grammatical, and also correctly describes what interpretations the relevant string has (Radford, 1997).

\section{PRoblems in TEACHING TENSES}

Tense is a matter of inflection that is the changing of the shape of a verb by adding or not adding a morpheme. It should be borne in mind that "tense" and "time" are not to be regarded as synonymous in English. The term "tense" is used to refer to a verb form, not to chronological time (Graver, 1986, p.50). English verbs are used to express the aspect (simple, continuous or perfect) of an action or event. To some linguists, structurally speaking, there are two main tenses; present and past. Future is included in the present. On the other hand, most of the linguists state that there are three tenses in English; present, past and future. There are some problems arising in the learning of the use of these forms because of the first language interference and existing distinctions in a different way.

The choice of verb form (simple, continuous, perfect) made by English speaker depends on many factors, and not on a rigid set of grammatical rules. For the foreign language learner it seems to be quite difficult to be able to use the language appropriately for the appropriate situations. As they haven't developed on the stressed points efficiently they fail to get the message across. Now, let's examine some of the tenses causing difficulties for learners to learn through the results obtained from the research.

\section{DATA ANALYSiS}

\section{A. Method}

The method used in this study is qualitative research based on document scanning which aims to figure out the commonly recurring errors in foreign language learners' written exams. Our aim here is not to analyze foreign language courses at Turkish State Universities but to evaluate the problems occurring during the teaching of grammar. It is not true that all lessons are conducted structurally, but while presenting the course it is inevitable to offer grammatical patterns. During this process, most of the foreign language teachers come across a lot of problems demotivating the lecturers.

\section{B. Procedure}

I have been teaching English for about 20 years. Except for two years, I taught English to Turkish students, for about 15 years to undergraduate students at a Turkish state university, Kirıkkale Universtiy, Turkey. Most of the learners at this university, as in other Turkish State Universities, have low-level linguistic background because they claim that they could not get foreign language courses in their previous education appropriately. Therefore, when they confront with the course they usually have problems. In this study, I found out that certain error types were made by Turkish students after analyzing hundreds of sentences produced by EFL learners' written exams. In order to obtain the related data, I took notes of the errors on the papers for three years.

\section{Participants}

The participants of this study are the first-year students at various faculties: Faculty of Education, Faculty of Art and Literature and Faculty of Engineering. As it is a compulsory course for them to succeed in a year of 60 hour-course programme devoted, they feel obliged to follow the course. The written exams administered to the participants from the 
first year students consisted of the questions requiring the grammatical knowledge of the learners. The exams of approximately 330 students (110 for each year) were scanned for three years in terms of the grammatical problems.

\section{Limitations}

This study only deals with the errors occurring in written exams administered to the first-year students at Kirikkale University. The participants are specifically chosen from the ones with different linguistic backgrounds who did not have any comprehensive language education before.

\section{E. Findings}

According to Harmer (2007:137) there are three groups of grammatical mistakes. Two of them are "slips", and "errors". When it is a "slip", students usually understand that they have made a mistake and are therefore able to correct themselves. On the other hand, 'Errors' require correction and explanation as learners do not have the language knowledge needed to correct these types of mistakes yet. Furthermore, the 'errors' can stem from two factors: L1 interference and as part of language development. In errors caused by L1 interference, the pupils' knowledge of the framework in which their own language is used, causes problems in their L2 or FL production when unfamiliar structures appear in the sense that the pupils use the familiar structure from their L1. On the contrary, developmental errors are produced by all language acquirers and learners in a natural language proficiency process (ibid). As our concern in this study is to figure out the most frequently made errors by Turkish learners, it is time to analyze them in detail. The following part specifically focuses on the errors occurring while teaching tenses.

a. Problems in Teaching Present Continuous and Simple Present Tense

The students misuse the present continuous as they confuse it with the simple present tense. The reason behind this misuse and misconception is that they can't keep themselves away from mother tongue interference. Let's examine some of the typical mistakes that the students make while learning and practising present continuous and simple present tenses.

TABLE 1

PRESENT SIMPLE AND PRESENT CONTINOUS TENSES

\begin{tabular}{|c|c|c|c|c|c|}
\hline & Erroneous Form Made by Turkish Learners & $n$ & $\%$ & Mean & Correct Form \\
\hline 1 & *I am playing football every Sunday. & 265 & 80 & \multirow{6}{*}{82.66} & I play football every Sunday. \\
\hline 2 & *They are living in Kirlkkale. & 302 & 91 & & They live in Kırıkkale. \\
\hline 3 & *I am not working on Saturdays. & 289 & 87 & & I don't work on Saturdays. \\
\hline 4 & *He isn't smoking. & 262 & 79 & & He doesn't smoke. \\
\hline 5 & * I am understanding you.. & 267 & 81 & & I understand you. \\
\hline 6 & *I am not liking this lesson. & 256 & 78 & & I don't like this lesson. \\
\hline
\end{tabular}

The mean score of 82.66 reveals that Turkish students usually confuse present continuous tense with the present simple tense. It can clearly be seen that the students utter the sentences as they are produced in their mother tongue. We, in colloquial Turkish, usually state the sentence 2 as "They are living in Kirıkkale", or "I am not working on Saturdays" for the sentence 3. "I am not smoking" is also another case that is uttered in the structure of present continuous in Turkish but refers to habitual activities of present simple. It should be reminded to the learners that the simple present, not the present continuous, should be used to express a present habitual action. Another issue to be considered is that the present continuous must be used for an action going on at the time of speaking.

Some of the Turkish students misuse some of the verbs denoting a state rather than an act. The verbs "understand, know, believe, like, love, mean, prefer, hear, see, belong, consist" and so on are used in the present continuous forms rather than present simple tense. These verbs mustn't be used in the present continuous but the present simple. To eradicate this problem, the foreign language teacher should focus on errors and provide the students with more practice.

b. Problems in Teaching Present Perfect and Simple Past Tense

To Richards (1979), the perfect in English creates problems for both elementary and advanced learners. It is interpreted frequently as an optional alternative to the simple past tense; this interpretation of its function leads to frequent errors of tense usage. Difficulties with the present perfect tense are often reinforced by faulty teaching. The basic uses of the perfect are outlined and contrasted with the functions of the simple past tense (p.95). The Present Perfect Tense is one of the most, probably the most, problematic tenses for Turkish students to learn. It is not easy to learn this tense correctly and to be able to use it appropriately for the appropriate situations as they have difficulties in understanding it. This tense is commonly confused with the simple past by most of Turkish students. The differences between the present perfect and past simple are complicated and difficult to analyse.

As is mentioned above, the students usually confuse the present perfect tense with the past simple. However, they need to be reminded that the past tense should be used for an action completed in the past at a stated time. The students should also be told that past simple is provided with the specific time expressions such as, "yesterday, last night/year/week, ago, then" etc. Let's examine some of the common mistakes of the learners. 
TABLE 2

PAST SIMPLE AND PAST CONTINOUS TENSES

\begin{tabular}{|c|c|c|c|c|c|}
\hline & Erroneous Form Made by Turkish Learners & $n$ & $\%$ & Mean & Correct Form \\
\hline 7 & * I have seen him yesterday. & 312 & 94 & \multirow{5}{*}{88.20} & I saw him yesterday. \\
\hline 8 & * A long time ago he has sold his car. & 284 & 85 & & A long time ago he sold his car. \\
\hline 9 & * He hasn't bought anything last week. & 301 & 91 & & He didn't buy anything last week \\
\hline 10 & * He hasn't died in the accident in 1989. & 277 & 83 & & He didn't die in the accident in 1989. \\
\hline 11 & * I lived in Klrlkkale since 1993. & 291 & 88 & & I have lived in Ankara since 1993. \\
\hline
\end{tabular}

Most of the students ( 88.20 mean) have also a tendency to use the past simple instead of the present perfect. Here are some of the other typical mistakes made by the Turkish students. Let's have a look at them and figure out what they confuse with.

TABLE 3

PRESENT PERFECT AND OTHER TENSES

\begin{tabular}{|c|c|c|c|c|c|}
\hline & Erroneous Form Made by Turkish Learners & $n$ & $\%$ & Mean & Correct Form \\
\hline 12 & *I am living in Ankara since 1990. & 256 & 78 & \multirow{7}{*}{85.66} & I have lived in Ankara since 1990. \\
\hline 13 & *He is sleeping for two hours. & 244 & 74 & & He has been sleeping for two hours. \\
\hline 14 & *I can't play football because I broke my leg. & 299 & 90 & & I can't play football because I have broken my leg. \\
\hline 15 & *Did you read this book? & 307 & 93 & & Have you read this book? \\
\hline 16 & *Did you see my book? I can't find it. & 301 & 91 & & Have you seen my book? I can't find it. \\
\hline 17 & *It is the first time I met him. & 293 & 88 & & It is the first time I have met him. \\
\hline 18 & * It is the best film I ever saw. & 289 & 87 & & It is the best film I have ever seen. \\
\hline
\end{tabular}

As it can be concluded through the examples and data ( 85.66 mean), the past simple is the only tense available in Turkish and it replaces the present perfect for all cases. Present perfect is also confused with present continuous tense by the foreign language learners. A good English teacher should help the students to differentiate the past simple and present perfect supplying them with efficient practice teaching materials. Otherwise, students won't be able to comprehend the language and this will lead to lack of communicative competence.

c. Problems in Teaching Past Continuous and Simple Past Tense

Past Continuous Tense is also another confused tense with the past simple. It is not as common as the other misused and confused tenses, but still some misconceptions and misinterpretation arise due to lack of practice and mainly mother tongue interference of the learners. In Turkish we normally say "Böyle yapacă̆ını biliyordum", which can be translated into English word-by-word with the past continuous tense, whereas the equivalent of the same sentence in English is "I knew that you would act in this way". The sentences produced in Turkish "1989'da Kirlkkale'de oturuyorduk (item 21)." Let's examine some of the sentences produced by the Turkish learners involving basically mother tongue interference.

TABLE 4

PAST SIMPLE AND PAST CONTINOUS TENSE

\begin{tabular}{|c|c|c|c|c|c|}
\hline & Erroneous Form Made by Turkish Learners & $n$ & $\%$ & Mean & Correct Form \\
\hline 19 & * I was knowing that you wouldn't come. & 289 & 87 & \multirow{4}{*}{86.50} & I knew that you wouldn't come. \\
\hline 20 & * She was working in a factory last year. & 276 & 83 & & She worked in a factory last year. \\
\hline 21 & * In 1989 we were living in Kirlkkale. & 284 & 85 & & In 1989 we lived in Istanbul. \\
\hline 22 & *I was smoking ten years ago. Now I don't smoke. & 301 & 91 & & I used to smoke ten years ago. Now I don't smoke. \\
\hline
\end{tabular}

Past continuous tense is also confused with the past habitual actions that should be expressed with "used to" to reveal that something happened in the past for a while and not continue any more. The mean score (86.50) proves that the participants have problem in comprehending past continuous tense.

Another issue to be considered is that most of the students at the beginning of learning process confuse past simple tense by generalising the past form of auxiliary "be" for the past simple tense. As it proceeds past simple in most of the coursebooks and syllabuses, most of the students attempt to use "was" or "were" for the all cases of the past simple. It is quite possible to confront such mistakes "I was go to school", "He was study English yesterday", "I was do my homework last night" and so forth.

What should be done, actually, is to practice on the related problematic tense as much as the students get the message. It wouldn't be fair to consider that all the errors made by the students are originated only from the mother tongue, as the mother tongue interference. In order to help the students retain the problematic tense in the correct form, the teacher should have enough time within his teaching syllabus for error correction and remedial teaching. Needless to say, to teach a tense quickly without making any drills, repetitions or drills cause these misconceptions in language teaching.

\section{DISCUSSION AND CONCLUSION}

The aim of this study has been to provide some general information about the problems that occur in language teaching, and present some suggestions to eradicate the common mistakes and errors arising in teaching and learning process. A good language teacher is the one who can observe the learners and figure out the problems while teaching tenses and present some solutions to diminish these problems. On the other hand, it should not be kept in mind that, as 
Brighton asserts (1994), errors will always be made, and have direct implications for remedial work because they are by their nature systematic infringements of the normal rules of the language. The teacher needs to plan his remedial treatment of them into syllabus for the coming weeks and moths. The insight that errors are a natural and important part of the learning process itself, and do not all come from mother tongue interference, is very important.

Remedial teaching is a kind of teaching activity that should be done by the language teachers when the problems occur while teaching any kind of teaching point, especially the problematic tenses for the students. However good the teaching and however effective the learning, there will always be a place for remedial work of one kind or another because it is beyond the capacity of a human being to absorb perfectly and retain indefinitely everything he is presented with (Broughton et al, 1994, p.133). Hence, from one point of view every learner needs remedial teaching after the first lesson. It is unfortunately common to find a student who is quite incapable of using the present simple or present perfect at the end of a teaching session.

There are of course some reasons that necessitate doing remedial teaching. There are circumstances quite beyond the teacher's control which produce remedial situation. The syllabus, for example, is usually not within the control of most ordinary teachers. The difficulty is that the students get indigestion from doing too much of one thing all together, and that once a topic is finished, and it is only incidentally referred to and practised later.

Another important factor which can produce poor learning and a potential situation is the many choices of materials to teach from. They must be suitable for the age groups of the students and suitable for the part of the world they are to be used in. Apart from the syllabus, the materials and the teacher, another potential source of trouble is the learner himself. Even with optimal conditions, there still is room for remedial work as there is no such thing as perfect learning. Clearly it is inevitable that learners do make errors.

It was a widespread belief until recently that contrastive analysis (comparing the learner's mother tongue with the target language) would predict the difficulties a learner would encounter and so enable the teacher to concentrate on them and avoid them. So it can be concluded that learners need remedial teaching when they don't understand the related tense well.

It is clear from this brief discussion that the learner brings with him one source of error: his mother tongue. Even more importantly, the learning process is the source of other errors. The most sensible course of action, with present knowledge, for the teacher is to reject the extreme positions. It shouldn't be considered that errors are wrong and must be avoided at all costs by very carefully. On the other hand, these incorrect forms are necessary, even vital, and should be actively planned into the teaching process. From the viewpoint it seems more useful and realistic to expose EFL students to a larger range of structure types in the first few weeks of an EFL course (Burt, 1975, p.62). They can also be used as a teaching material to present some tenses to attach the attention of the learners on. What is more, errors are natural outcome of learning.

\section{REFERENCES}

[1] Broughton, G et al. (1994). Teaching English as a Foreign Language. London: Routledge.

[2] Burt, K. M. (1975). Error Analysis in Adult Classroom. TESOL Quarterly: Voul.9, No.1 p.62

[3] Chomsky, N. (1959). Review of Skinner's Verbal Behavior. Language, 35: 26-58.

[4] Cyrstal, D. (1992). An Encyclopedic Dictionary of Language and Languages. Oxford: Blackwell Publishers.

[5] Fitikides T.J. (1978). Common Mistakes in English. Singapore: Longman.

[6] Gokhale, Madhuri. (2010). Research Paper: 'A Pragmatic Approach to the Teaching of Grammar in Indian Context'. Elt Weekly, Vol. 2 Issue 75 November http://eltweekly.com ISSN 0975-3036.

[7] Graver, B.D. (1986). Advanced English Practice. Oxford: Oxford University Press.

[8] Harmer, Jeremy. (2007). The Practice of English Language Teaching. 4th ed. Harlow: Longman/Pearson Education.

[9] Hutchinson, T. (1987). Using Grammar Books in the Classroom. Oxford: OUP.

[10] Larsen-Freeman, D. (1991). Teaching Grammar. In M. Celce-Murcia (ed.) Teaching English as A Second or Foreign Language, Boston, M.A: Heinle and Heinle.

[11] Leech, G. and Startvik, J. (1994). A Communicative Grammar of English. New York: Longman.

[12] Swan, M. (1982). Practical English Usage. Hong Kong: Oxford University Press.

[13] Radford, A. (2003). Syntax. Cambridge: Cambridge University Press.

[14] Richards, C.J. (1979). Introducing Grammar the Perfect: An Exercise in Pedagogic. TESOL Quarterly, Vol. 13. No.4.

[15] Rivers, M. W. (1981). Teaching Foreign-Language Skills. Chicago: The University of Chicago Press.

[16] Ur, Penny. (1996). A Course in Language Teaching: Practice and Theory. Cambridge: Cambridge University Press.

İsmail Çakır is an assistant professor at the English Language Teaching Department, Faculty of Education, Erciyes University, Turkey. He has several publications on foreign language teaching. His interest is in foreign language teaching, teaching language skills, process writing, teaching reading, teaching culture. 